\title{
Geological photo-interpretation of Hall Land: part of the regional topographical-geological mapping of northern Greenland
}

\author{
Peter R. Dawes
}

The northern margin of Greenland is composed of a sedimentary basin that stretches over $1200 \mathrm{~km}$ from the west to the east coasts. As the search for energy resources intensifies and widens attention is being focused on the hydrocarbon potential of this vast sedimentary terrain. During the last decade, GGU has carried out on a limited scale, and often based on joint logistic support, a number of stratigraphical and structural reconnaissance investigations in selected areas throughout northern Greenland. However, in an attempt to meet the growing need for more detailed knowledge of the region, planning began some years ago for a systematic regional geological mapping programme - now scheduled to start in summer 1978.

\section{Topographical and geological mapping}

A major part of this planning period has been an assessment of the quality of the existing topographical map material. In short, the region north of $78^{\circ} \mathrm{N}$, a total ice-free area of 130000 $\mathrm{km}^{2}$, is fully covered by the American AMS map series, scale 1:250000; maps that were constructed from post-war trimetrogen aerial photographs by the Army Map Service. Danish coverage of the region is restricted to the primitive, pre-war, coastline charts at a scale of 1:300000 (Koch, 1932).

Comparison of the AMS maps with aerial photographs indicate frequent cases of nonrepresentation or violent misrepresentation of geographical features. Canadian and British ground surveys demonstrate the large mapping errors and the severe distortion and inaccuracy in scale of the maps (Lillestrand et al., 1968; May et al., 1972). The true coordinate position of a geographical feature can vary by about $25 \mathrm{~km}$ from the map coordinate and Lillestrand \& Johnson (1971) conclude that northern Greenland is about $8000 \mathrm{~km}^{2}$ larger in area than depicted by the AMS maps.

Field work in northern Greenland is particularly costly; the coasts are ice-locked throughout the year and logistics are difficult. The scarcity of reliable control points, coupled with the fact that a detailed cartographical survey is not imminent, has led to an investigation of methods of constructing topographical maps by untraditional methods (Dueholm, 1973).

Fortuitously northern Greenland is well suited to geological mapping involving advanced use of aerial photographs. A major part of the terrain is composed of homoclinal platform strata. In principle such terrain can be relatively quickly mapped by the establishment of several standard sections in the field and the eventual projection of mappable units between the sections by photogrammetrical methods.

A research project supported by the Danish Natural and Technical Science Research Councils (SNF \& STF) and GGU was initiated in 1975 by K. S. Dueholm at the Institute for Surveying and Photogrammetry, Technical University of Denmark. This has the aim of evaluating how much geological information can be obtained in the laboratory using aerial 
and satellite photographs and advanced photogrammetrical techniques, and how topographical and geological mapping can best be combined.

Various regions in northern Greenland are to be studied in the project. Hall Land was the initial region investigated and this note briefly describes some of the main results of the photo-interpretation and compilation of a geological map.

\section{Instrumentation}

A 'Zeiss F-2 Planitop Topographic Plotter', a second order analog instrument designed for plotting at medium to small scales, was used in the exercise. Model coordinates can be digitalised by linear electronic pulse generators and handled by an automatic registration system. Automatic plotting of topographic contours, as well as geological structures can be made routine with quantitative elements, such as strike and dip of planar structures, plunge of fold axes, thickness of units, throw on faults, etc. being calculated by computer programmes.

The instrument can be easily operated without prior training. Control of the floating mark and the tracing head are combined in a single hand operated terrain carridge. This allows for rapid and accurate movement within the model. The automatic altitude scale and the fact that the actual plotting takes place in front of the operator on an illuminated integral tracing table for scales within the range $\times 0.5$ to $\times 1.5$, are two features that assist greatly in geological interpretation and mapping. Accessory mechanical or digital tracing equipment can be attached for larger scale magnifications. The use of diapositives instead of positive paper prints leads to the identification of features that otherwise would not be recognisable.

\section{Work procedure}

Aerial photographs at the scale of about 1:58000 were supplied through Greenarctic Consortium, a Canadian commercial company. Photogrammetrist Ole Ørslev orientated the diapositives in the instrument and was responsible for plotting out various physiographic and straight forward geological features as well as the topographic contouring.

The aerotriangulation of Hall Land consists of 76 models, each covering about $50 \mathrm{~km}^{2}$. The field of view in the instrument is about $2.25 \mathrm{~km}^{2}$. The exercise was to extract and plot out as much geological detail as possible with a view to publication of the map at 1:100000. The plotting scale was accordingly fixed at 1:50000.

\section{Location and general geology}

Hall Land is situated between $81^{\circ}$ and $82^{\circ} \mathrm{N}$ on the northern coast bordering the Robeson Channel (fig. 9). The region exhibits a cross-section through the North Greenland geosyncline from the shallow northerly dipping carbonate platform of the south to the fold belt of the northern coast. A central low-lying area composed of Quaternary deposits conceals the junction between these two provinces.

Apart from Lauge Koch's (1920) pioneer work, geological study has been restricted to the U.S. military Operation Groundhog 1958-59, that resulted in a geological sketch map at 1:700000 (Davies et al., 1959) and GGU's work in 1965 that amounted to some 30 working days from 7 field camps (Allaart, 1965; Dawes, 1971). 


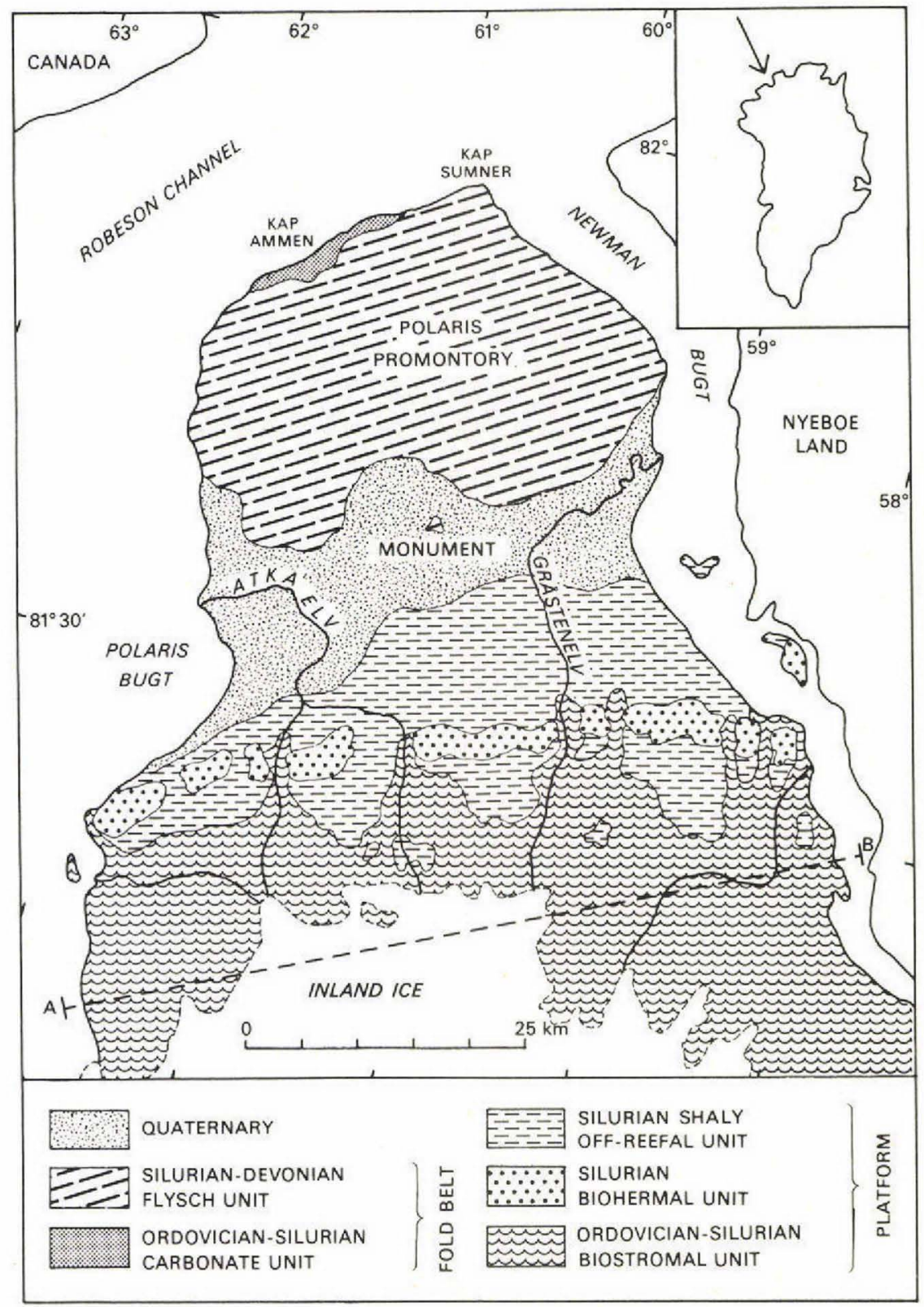

Fig. 9. Geological sketch map of Hall Land, North Greenland. Line A-B indicates the southern limit of the 76 model study area used in the photo-interpretation. 
Fold belt

Main outcrops in the fold belt are of a monotonous Silurian-Devonian flysch $(c .1200 \mathrm{~m}$ thick) in which little stratigraphy can be recognised. This overlies an Ordovician-Silurian carbonate sequence $(550 \mathrm{~m})$ that is only exposed along the steep cliffed coastline of the northern coast. Here various units were distinguished and mapped in the carbonate sequence and in the lower part of the flysch. Using oblique photographs, measurements in a stereo-comparator have been carried out by $\mathrm{K}$. S. Dueholm to determine the true thickness of these units.

Whenever visible, bedding traces have been plotted. Many areas in the north-east are characterised by closely spaced east-west trending folds with clear examples of closed structures. Some localities suggest refolded isoclinal folds. Structural measurements of bedding and plunge of fold axes have yet to be undertaken.

Certain thickness variations and irregularities in bedding may represent carbonate mound formation, rather than for example tectonic variations due to thrusting. Such occurrences need to be checked in the field. From other evidence the presence of a shelf environment off the present coast in late Ordovician and early Silurian time seems likely (Dawes, 1976).

\section{Platform}

The platform is dominated by an extensive Silurian reef complex that from field observations is known to display spectacular facies relationships (Dawes, 1971). Three units (essentially different facies) have been mapped: a lower unit of relatively dark, variably banded biostromal limestones and associated patch reefs, a unit of white to light grey, massive biohermal limestones and associated breccias that form an E-W range of hills (the Hauge Bjerge), and a dark, thin-bedded off-reefal unit containing a variety of shales and argillaceous limestones.

The relationship of these units is complicated. Facies changes can be transitional over tens of metres or quite abrupt. The biostromal unit, in which some stratigraphy can be recognised, forms a substratum on which the main reef build-up developed. The off-reefal rocks are the facies equivalents of the biohermal unit, as well as to a lesser extent the underlying biostromal unit, and they form back-reef and fore-reef belts more extensive than previously thought.

The bioherms can display steeply dipping bedding and it is not uncommon that a $300-400$ $\mathrm{m}$ thick bioherm grades over a short distance into substantially thinner ( 25 per cent or less) off-reefal beds. Slumping of shales and limestone is also common on the flanks of bioherms.

The abrupt facies boundaries can be difficult to distinguish from fault contacts, since numerous $\mathrm{N}$ to $\mathrm{NE}$ faults traverse the platform. To the south of the Hauge Bjerge, off-reefal beds within biostromal limestone terrain can form topographically low outcrops. In some examples faults cannot be detected and the relationship seems not to be one of facies change. Thus, the question of important unconformities, originally proposed by Koch (1929) in the Silurian sequence must be investigated in the field. 
Quaternary terrain

Quaternary rocks form a broad belt of continuous outcrop across central Hall Land (Davies et al., 1959). Five groups of deposits have been mapped in this belt; glacial, marine, fluvial, colluvial and lacustrine, as well as a number of periglacial and aeolian features. For consistency, the Quaternary geology has also been extended onto the fold belt and platform terrains. New data gained from the present photo-interpretation is summarised below.

1. Marine deposits, mainly grey, fine-grained silt occupy a much larger area than hitherto thought (Davies et al., 1959; Davies, 1972) forming large areas of the central plain and along Polaris Bugt and Newman Bugt.

2. The marine outliers seem to post-date the prominent end moraine systems that flank Polaris Bugt and Newman Bugt and indicate the former extent of the Inland Ice. The northernmost moraines parallel to the coast occur about $10 \mathrm{~km}$ south of Kap Summer.

3. An extensive system of raised shore.lines has been mapped $25 \mathrm{~km}$ inland from Polaris Bugt to the south-east of the Monument, abutting against north-south trending moraines. This indicates a marine limit of at least $110 \mathrm{~m}$.

4. A lobe-shaped marginal moraine, to the south-west of Kap Ammen, was presumably produced by a glacier that could have reached Greenland from Ellesmere Island.

5. The quality of detail afforded by the diapositive prints and the automatic registration of altitude afforded by the instrument have allowed various structures to be mapped and interpreted, e.g. patterned ground, ice wedges, and marine and fluvial terrace systems. An illustrative example is that orientation of barchans on the extensive raised terraces of the Gråstenelv indicate a strong and persistent westerly wind direction.

\section{Conclusions}

The mapping of some $4000 \mathrm{~km}^{2}$ of Hall Land is based on a minimum of field work. During this the main rock units, their general age, and the nature of boundaries between them were established and some structural data collected. Using this information, the regional extent and outcrop pattern of the units have been interpreted photogrammetrically and a geometrically precisely accurate geological map at 1:50 000 has been compiled. Production of a comparable map by traditional field methods is impossible because of the lack of a topographical base. However, assuming it were, the mapping would demand an intense and extended period of field work, in view of the remoteness of the region, spanning several summers, and the resultant map would be more costly to produce and less geometrically accurate. The restricted field of view in the instrument and the somewhat time consuming method of orientation make the method considerably less suitable for reconnaissance compilation and the preparation of small-scale maps involving a substantial number of models from which only a minimum amount of geological information is required.

The use of photogrammetrical methods increases the amount of geological mapping that can be achieved in the laboratory, increases the accuracy of certain data, provides a method of gaining geological data from difficult or inaccessible terrain, and thereby reduces field work (Dueholm 1976). Their value in the compilation of large-scale maps in areas like northern Greenland, where only poor topographical map coverage exists is outstanding. Nevertheless the importance of field observations should not be overshadowed, and it must be stressed that the Hall Land map project can only be fully assessed after a rigorous checking of the map in the field. 


\title{
References
}

Allaart, J. H. 1965: The Lower Paleozoic sediments of Hall Land, North Greenland. Grønlands geol. Unders., Unpubl. rep., 11 pp.

Davies, W. E. 1972: Landscape of Northern Greenland. Spec. Rep. Cold Reg. Res. Engng Lab. 164, 67 pp.

Davies, W. E., Needleman, S. M. \& Klick, D. W. 1959: Report on Operation Groundhog (1958) North Greenland. Investigation of ice-free sites for aircraft landings, Polaris Promontory, North Greenland. 45 pp. Bedford: U.S. Air Force Cambridge Res. Lab.

Dawes, P. R. 1971: The North Greenland fold belt and environs. Bull. geol. Soc. Denmark 20, 197-239.

Dawes, P. R. 1976: Precambrian to Tertiary of northern Greenland. In Escher, A. \& Watt, W. S. (edit.) Geology of Greenland, 248-303. Copenhagen: Geol. Surv. Greenland.

Dueholm, K. S. 1973: Untraditional topographic mapping in central West Greenland. Rapp. Grønlands geol. Unders. 65, 26-28.

Dueholm, K. S. 1976: New instruments for geological photo-interpretation and mapping. Rapp. Grønlands geol. Unders. 80, 144-148.

Koch, L. 1920: Stratigraphy of Northwest Greenland. Meddr dansk geol. Foren. 5 (17), 78 pp.

Koch, L. 1929: Stratigraphy of Greenland. Meddr Grønland 73 (2), 2, 205-320.

Koch, L. 1932: Map of North Greenland, scale 1:300000, 18 sheets. Copenhagen: Geodetic Institute.

Lillestrand, R. L. \& Johnson, G. W. 1971: Cartography of North Greenland. J. Amer. Congr. Surveying Mapping, 31, 233-250.

Lillestrand, R. L., Johnson, G. W. \& Wells, D. E. 1968: Analysis of measurements made in northern Greenland during Project Nord - 1968. 99 pp. Minneapolis: Control Data Corp.

May, H. P., Reid, B. K. \& Dalton, A. D. F. 1972: Annex A, Survey report. In Joint Services Expedition, North Peary Land, 1969, 11 pp. London.

\section{Cambrian-Silurian studies in Washington Land, western North Greenland}

\author{
John S. Peel
}

The geological programme commenced in Washington Land during 1975 (Henriksen \& Peel, 1976) was continued at an amplified level during July and August 1976 when parties from the Geodetic Institute and the Institute for Surveying and Photogrammetry, Technical University of Denmark, joined three groups from GGU in a combined operation. The natural landing strip at the eastern extremity of Cass Fjord (fig. 10) again served as a base camp, but parties worked throughout Washington Land with support from a Greenlandair Charter Bell 204 helicopter periodically travelling north from Thule Air Base.

The party from the Geodetic Institute, Copenhagen, were primarily engaged in conventional triangulation and the establishment of positional coordinates using satellite-Doppler instrumentation, as a preliminary to possible remapping of North Greenland. The group from the Institute for Surveying and Photogrammetry, led by Keld S. Dueholm spent the 